\title{
Money Dwells in the Spiritual Pocket! The Gospel of Prosperity and the Empowerment of Women through Talents/Matarenda among ZAOGA FIF Adherents in Gweru, Zimbabwe ${ }^{1}$
}

\author{
Gilbert Tarugarira and Annah Moyo \\ tarugarirag@staff.msu.ac.zw \\ moyoan@staff.msu.ac.zw
}

\section{Abstract}

Some religious movements have instilled a creative and innovative spirit among their adherents. This spirit is coupled with hard work and the inculcation of skills towards making a better life for themselves and their families. Referring to the Zimbabwe Assemblies of God Africa - Forward in Faith (ZAOGA FIF), this essay explores how this church organization has instilled hard work, frugality, and penultimate economic empowerment among its followers through Talents/Matarenda. The essay has employed the Empowerment Framework of Longwe and Clarke (1994) as an analytical tool to unpack the church's approach towards the empowerment of women. It has established positive changes in people's quality of life amidst conflicts and compromises between the maintenance of religious ethical standards and the primacy of the economic motives in the adherents' quest for material wealth.

Keywords: Empowerment, networks, ethical standards, gender, thrift, Third World mentality, gospel of prosperity

1 The Faculty of Education at Midlands State University in Zimbabwe gave their consent for this research on May 28, 2018. On June 17, 2018, ZAOGA gave the researchers permission to visit the church districts in the Midlands Province. 


\section{Introduction}

The gospel of prosperity has arguably brought fortune and a considerable amount of wealth to both believers and leading clergymen in Africa, among whom is Ezekiel Guti, the founder of ZAOGA (Mwase 2012). Guti's 'leadership style and expensive overseas trips and the lavish lifestyles of some of his more powerful pastors' (Melton \& Baumann 2010:3189), confirm a shift from a doctrinal approach of spiritual purity and personal godliness to the gospel of prosperity (Anderson 2001:115). Founded by Guti (a carpenter by profession) under a gum tree in Bindura on May 12, 1960, the church has now established branches in more than 180 nations worldwide (Gwaze 2019). According to Melton and Baumann (2010:3189), '[b]y 1999 ZAOGA had an estimated 600,000 affiliated members, which made it then the third largest church in Zimbabwe after the Marange Apostles and the Roman Catholics'. In 2010, ZAOGA itself claimed to be the largest church with more than two million members. Having quickly spread its wings beyond the borders of Zimbabwe, ZAOGA has remained 'one of the fastest growing transnational Pentecostal churches' (Maxwell 2006:74).

We did not labor much on historical narratives surrounding the growth of the church and the multifaceted challenges which the church might have witnessed. A striking feature which motivated the research was the hegemonic pervasiveness of the church's gospel of prosperity through Talents (Matarenda) in giving birth to, nurturing, and molding successful businesspeople from amongst women who are regarded as society's marginalized lot. Talents is analogous to the biblical work ethics derived from Matthew 25:14-30 where a master gave talents to his servants who in turn acted differently in response to the gesture. Proverbs 10:4 states that [l]azy hands make a woman poor but diligent hands bring wealth. This verse is quoted to closely associate women with the working of Talents. While ZAOGA has the African Christian Business Fellowship (ACBF) ministry which helps people to secure advice on starting and planning businesses, this essay has deliberately done research on Talents which have a historical alignment with the empowerment of women right from grassroots level.

We have established that, while religion has been a powerful source for the subordination of women in society, it has also turned out to be an important universal source for the feminist movement and other social and political movements for human liberalism. This is particularly evident in that 
the church has provided women with opportunities for leadership, education, and the development of organizational skills. It is true that 'Christianity attracts women to a greater degree than men, who indeed have little to lose and much to gain from embracing it' (Pauw 1974:422). ZAOGA's doctrine of Talents embraces what Martin (1990:206) has termed 'penny capitalism', which embraces the "vending of cheap foodstuffs and clothes, initially within the religious community but later externally, to finance the expansion of that community'. Maxwell (1998:355) observes, 'ZAOGA members are well known at borders which they cross regularly to buy bales of clothes, blankets and electrical goods for sale'. In some respects these members would behave 'no differently from many other Zimbabwean women who have turned to self-reliance in the face of the desertion or absence of the male wage-earner, or in response to the rising cost of living' (Maxwell 1998:355).

Of interest in this essay is assessing the extent to which the church doctrine has transformed the Christian women's attitude towards wealth, poverty, and private ownership of property, amidst the need to preserve spiritual dignity. Africans in general and Zimbabweans in particular 'have been inexorably drawn into a new kind of society, at once commercial, industrial and urbanised in which the value placed by Christianity on individualism and self-reliance is a fillip to achievement' (Nürnberger 1990:162). These developments have opened the door for Pentecostalism and rendered it attractive. The church now 'exercises a strong organisational appeal, becoming the focus of a rich and varied pattern of associational life, which now fulfil many of the functions of the ailing indigenous or traditional kinship group' (Pauw 1974:426). Van Dijk (2002:50) proffers that 'many of the new Pentecostal churches appear to pursue a gospel of individual prosperity, emphasize private enterprise, pursue business interests and certainly venerate their influential leaders in a kind of personality cult'.

\section{Theoretical and Conceptual Framework}

This essay is broadly rooted in the feminist theory which embraces the social, political, and economic equality of sexes. According to Burton (2001:62), 'the feminist theory exists in a variety of disciplines emerging from feminist movements and related theories about the origins of inequality and the social constructions like gender'. Within this theory, Christian feminism is found, 


\section{Gilbert Tarugarira \& Annah Moyo}

with the aim to interpret and understand Christianity in light of the equality of men and women (Kohm 2008:341). Christian feminists argue that God does not discriminate on biologically determined characteristics such as sex. ZAOGA has embraced an African theology which addresses the condition of women. Such a theology is more an 'indigenous feminism' than an imported Western feminism (Bayu 2019:55). ZAOGA's agenda is different from Western feminism because its roots are anchored in the black community and the black or indigenous church. Such a perspective resonates with the Women's Empowerment Framework of Longwe and Clarke. Longwe, a Zambian woman activist, argues that 'most of the development has concentrated on ensuring equality between women and men in various sectors like education and employment' (Longwe \& Clarke 1994:75). This has tended to leave women out of the socio-economic development framework. For Longwe, 'development means enabling people to take charge of their own lives and escape from poverty' (Longwe \& Clarke 1999:92). Longwe and Clarke (1999:93) further posit that 'where men have vested interests to continue to subordinate women, it is folly to expect them to realise the value of gender equality and give women an equal share of the cake'. Longwe and Clarke's Women's Empowerment model gives a developmental framework rooted in the feminist theory in which the 'process of empowerment is better understood in terms of five levels namely: welfare, access, conscientisation, participation/mobilisation and control/empowerment' (Longwe \& Clarke 1994: 77). This framework has been used to analyze ZAOGA's degree of commitment to the empowerment and development of women through Talents.

The level of welfare forms the bottom feature of the empowerment framework of Longwe and Clarke (1994). At this level, employment is basically viewed as enhancing women's material welfare in relation to men. In this case, it is men who confer upon women some gifts, favors, and materials without the recipients' involvement in their accumulation. At this level, there is zero empowerment, since the development interventions are there to meet basic needs rather than the enlightening and empowering of women. The level of access is viewed as women's equality to men in terms of accessing the means of production.

For Longwe (1995:48), 'equality of access can be achieved by observing the principle of equality of opportunity which often requires reforms in gender based discriminatory and administrative practices of the land or organisation'. The level of conscientization is a situation whereby 
women have access to information from higher authorities. This marks the beginning of conscientization or awareness that their gender roles can be changed despite what culture or the Bible says, recognizing that women subordination is not a natural order of things. The level of participation or mobilization entails females who are taking part in administrative tasks which include crafting or designing policy issues as equals to their male counterparts. In church it would mean that women who are conscious of discriminatory practices, are coming together to remove those practices and regulations in the church. The level of control and empowerment calls for the equal dispensation of authoritative decisions as a result of training and experience. At this stage, decision-making should see women taking control over production and distribution. Women in the church would therefore increasingly occupy meaningful positions in the church.

For this essay, the model restricts the concept of empowerment to a situation where women play a major role in achieving development so that they can be in charge of their livelihoods and escape from poverty. Zimbabwe, through its gender policy, acknowledges that women's economic empowerment is key to the country's socio-economic growth. In addition, the Zimbabwean government has prioritized sustainable development goals that address gender equity, poverty reduction, and value addition as key for its 2030 development agenda. The policy on economic empowerment of women resonates with many of its other policies and partnerships. Kabeer (2001:22) defines 'empowerment' as the 'expansion in people's ability to make strategic life choices in a context where this ability was previously denied to them'. These life choices, according to Fox and Romero (2017:16), include 'their right to have access to opportunities and resources, the right to have power to control their own lives, both within and outside the home, and their ability to influence the direction of social change to create a more just social and economic order'. In this study, empowerment embraces the inculcation of skills and capacity for self-reliance, the ability to make choices in life and to control resources (economic), and an inner strength to sustain the gains which women accrue. With an increased capacity building support from the church through Talents, this essay advances that ZAOGA women have managed to eliminate poverty by improving their families' standard of living. 


\section{Methodological Issues}

The research done for this essay was largely qualitative in nature. The focus was on how ZAOGA believers view Talents as they relate to broader religious discourses, specifically the empowerment of women. Hence, the study was based on formal and informal interviews with ZAOGA bishops, overseers, pastors, chairladies, and secretaries of women's groups, vendors, cross border traders, and businesswomen within the church's seven administrative districts of Gweru urban, namely Gweru City Christian Centre, Southview, Mkoba 1, Mkoba 2, Senga, Harben Park, and Ascot. On the geographical location of the districts, we have accepted the tripartite division of society in upper, middle, and lower classes, reflective of the high-, medium-, and low-density suburbs where saints resided. In view of the fact that there are always borderlines of transition and uncertainty between each of the three class categories, errors in the placement of particular saints might have been made.

Our major interest, though, was dealing with one aspect of the fairly rapid progress of saints from the 'stable to the palace' in terms of moving from the high- to the low-density residential suburbs. Participants in the study were purposively selected, based on socio-economic variables concerning the church community under study. These variables were measured through questionnaires that asked the respondents several factual questions about themselves, their families, and their places of residence in a bid to discover some of the salient social circumstances involved in the choice and making of ZAOGA saints. This approach helped to address contestations over the doctrine of Talents' contribution towards changing class relations within the movement (Maxwell 1998:362). Participant observation of sermons was conducted and the messages of these sermons was contextually analyzed.

We also made use of focus-group discussions. The focus groups invigorated a variety of responses, providing a better awareness of the perceptions, attitudes, and opinions of the participants concerning the relevance, feasibility, and sustainability of Talents towards women empowerment and poverty reduction at community and household levels.

It is also worth noting that the first author of this essay is a member of ZAOGA who has been exposed to the mode of operation surrounding the working of Talents. Obviously, this presented the challenge to negotiate identity from a believer to a researcher. An attempt was thus made to mini- 
mize bias as much as possible. This emic approach, however, afforded researchers to make informed deductions from observations and eyewitness accounts without any challenges. Biri (2014:140) confesses having taken advantage of his long history of membership of ZAOGA towards the production of an authentic account of the church's political theology of mobility and the development of ZAOGA's diasporic communities. He (Biri 2014) admits having benefited tremendously by drawing on testimonies, teachings, and sermons in church services that he attended over a decade.

The second author of this essay is an ardent Catholic. While undertaking our analysis of issues, we were therefore aware of our own religious affiliations. We recognized that the groups to which we belonged had the potential to guide our interests and orient our observations. However, we were convinced that the magnitude of the aspects under consideration would not attract modes of subjectivity amidst our own orientation and the requirements of sound methodology. Biri (2014:143) concurs that the practice of Talents is not questioned within ZAOGA, 'rather it is an intrinsic part of the church's founding narrative'. We wish to stress that we considered our religious belonging in the perspective of social participation, acknowledging that within a single church, belonging exists with notable variations ranging from regular participation in worship to sporadic identification.

\section{Guti on the Spirit of Poverty and Third World Mentality}

The purpose of this section is to provide a broader understanding of poverty in Guti's teachings than is normally understood and quoted. The misery characterizing the developing world compels one to ask how people can talk about a just and merciful God in the face of all the suffering. The circumstances of the encounter between Christianity and Africa are well known and leave one with the suspicion that Christianity came with an attitude of superiority. Bujo (1993:135) specifically refers to Genesis 9:18-27 which narrates Noah's cursing of Canaan, the son of Ham. This text was understood in the Christian tradition as showing that God cursed the black people as a consequence of the sin of their father, Ham. Guti (1994:51) strongly argues that Africa is not cursed but blessed, adding that a drunken person could not put a curse upon people. In 1993, Guti organized and hosted the International Christian Leadership Summit for Africa and the Caribbean (ICLSFAACA) in 


\section{Gilbert Tarugarira \& Annah Moyo}

Harare. Addressing 5,000 delegates from 52 different churches from 19 countries, mostly from Africa, Europe, America, and the Caribbean, he challenged both the governments and the churches in the Third World, especially Africa to look up to God to solve the poverty and the wars which are destroying people.

Guti has always advocated for an African Christian theology whose teachings and direction are originating from Africa and not from outside, so that the church could not be considered as a hangover from the colonial past. True churches, he argues, must arise and be a blessing to Africa: 'Africa needs prosperity not poverty, unity not division, development and not destruction' (Guti 1994:73-74). He has also called for preaching the importance of a black man and his identity. In a message for the nation which he delivered at the National Big Sunday on February 7, 1988 in the National Sports Stadium, he told the gathering:

When our black people see the white people, they see money and they beg for money. They think that white skin is money...Money is when you use your brain fully. That is why our people want to be servants of white people. They trust whites better than their own people. This is what 1 call third world mentality (Guti 2000:74).

Guti argues that Africa must distance itself from being labelled a dark and pagan continent through being self-reliant and self-supportive. Africa must desist from being dependent upon outside support. At a Deeper Life Conference in Harare, Guti encouraged people not to become what they study. $\mathrm{He}$ remarked:

If you study law, you become an attorney, and a study of auto mechanics makes you a mechanic. The mistake in becoming what you study is that too many people forget to mind their own business. They spend their lives minding someone else's business and making that person rich...Churches should...influence African people into establishing businesses in a clean manner without an element of corruption (Guti 1994:22, 64).

He has always questioned how the gospel could become good news to the poor if the people remain poor. The gospel can only become good news when 
it heals the people who are broken-hearted by poverty and sickness and brings deliverance to the captives who are oppressed by poverty and ignorance. On the economy in the Third World, he has called people to pray to God to set them free from the mentality of dependency. Addressing a gathering of the ACBF, Guti stated:

The other problem we have in the third world countries is that some of our businessmen and women do not know how to think and plan properly for themselves. They wait for multinational companies to think for them and as a result they tighten third world economy. It is now time for Africa and all third world nations to think for themselves...In the third world countries our people are just waiting for hand-outs and some of them do not want to work anymore but only to receive (Guti 1994:68).

Various scholars attribute the growing dominance of Pentecostal apostles and prophets to the poor socio-economic and political contexts in Zimbabwe (Chitando 2013; Maxwell 2006; Togarasei 2005; Magezi \& Banda 2017). As mentioned earlier, ZAOGA 'appropriated a version of the prosperity gospel in line with African sentiments which place a strong emphasis on black pride and self-actualisation' (Maxwell 1998:371).

Guti has supported the land redistribution exercise in Zimbabwe and encouraged church members to work hard in order to buy land. Guti believes that owning land, either for residential purposes or farming is a form of black empowerment after the dispossession by the colonial settlers. He advised church members, "Toraivo ivhu zviri kuita vamwe. Hariruzi value"2 (Biri 2013:115). Maxwell (2002) succinctly discusses the relations between ZAOGA and politics in post-colonial Zimbabwe. His sentiments are echoed by Biri (2013:115) who castigates Guti for supporting the former president of Zimbabwe, Robert Mugabe's theology of land which was characterized by all forms of violence. By contrasting Guti's leadership to that of Mugabe, both of them failed because Mugabe grew more removed from his people and more unpopular, whereas Guti came closer to his people and even became more popular. What remains evident is that much of Guti's preaching and

2 Grab the land just like others are doing it. Land does not lose value. 
writing has remained focused on resurrecting or resuscitating the African image from racial bigotry perpetuated by the colonial system.

\section{The History of Talents}

Although the issue of Talents is said to have been pioneered by Nicholas Bhengu, the leader of the Assemblies of God (South Africa) during his 'Back to God' campaign in Highfield in 1959, Maxwell (2006:215) notes that Guti's initial enthusiastic promotion of Talents derived from his mother, Dorcas whose industriousness and creativity held her family together. In his emphatic dismissal of the claims that ZAOGA received financial and other resources from America, Guti considers Talents as a strategy which God revealed to him to get money for the spreading of the gospel. When he was in the USA for studies, he was approached by a business tycoon who was willing to sponsor the church, provided that Guti submitted wholly to the businessmen's leadership. After praying to God for an answer, God is said to have said to Guti, 'If you humble yourself and obey me, I will be your money' (Guti 2000:57). God instructed him to teach the people about his (God's) word and teach them to give and work Talents (Guti 2000; 2015; Maxwell 1998; 2006; Martin 1990; Biri 2014; Gifford 1988).

When Guti came back from the USA in 1972, he taught people about giving to God and working Talents as the Lord had instructed him. According to Biri (2014:141), Guti returned home with a spiritual assurance that if the people were to pay their tithes and work tirelessly, God would enrich them. While the ideas underpinning the School of Talents were borrowed from the Bible, ZAOGA later perfected it by one of the school's cofounders, Priscilla Ngoma who encouraged women to be industrious and accumulate wealth. ZAOGA discourages idleness and the 'folding of hands' (Gifford 1988:68). It is important to note that although men, women, and youths are encouraged to do Talents in ZAOGA, this aspect of the church's teaching is specifically targeted at women (Biri 2014:155; Maxwell 2006). Maxwell (2006:255) also attaches a feminine image to Talents. There is a need to reiterate that, although men and children also volunteer for Talents, it is a predominantly female activity.

Maxwell (1998:371) observes that Talents are presented every three years, stretching over six months. However, the timing has continued to 
change over time according to different projects in the church which need resources. Saints would make commitments of amounts for which they would work, and then they started to work towards their targets. As indicated later in this essay, meetings and services would be carried out to motivate and encourage members to work. The practice in ZAOGA is that Church and Home Talents alternate annually, bi-annually, or as pronounced by the founder of the church, Archbishop Guti. Money from Home Talents is meant to improve individual households and not church activities. This distinction is crucial because it is Home Talents which resonate with industriousness for self-sufficiency. Guti (2015:6) avers that Talents are "not a way of the church getting money from people, but the church enriching the believers on how they themselves can have money and come out of poverty'.

Tangible evidence of the success of Talents manifests in a number of ways. In 1991, women gathered Church Talents to the amount of Z $\$ 4$ million (Guti 2000:30). The money was used to build flats at the Africa Multi-Nation for Christ College (AMFCC). The 1993 Home Talents saw people buying cars and others building their own houses. Talents, according to Guti, are 'a school which trains every woman in ZAOGA-FIF to be self-sufficient and to be skilled in business; to help her own family by bringing income to the home through using her own hands' (Guti 2000:156; 2015:32). In 1995, Church Talents raised Z $\$ 13$ million which was used to buy 20 new Nissan Pickups for the overseers, three new lorries, two minibuses for the Go Quickly and Tell team (a women's group), houses for overseers and provincial administrators, and two large crusade tents (Maxwell 2006:155; cf. also Biri 2014). According to Guti (2000:24), '1995 was a year of deliverance from the spirit of poverty'. Through Church Talents, ZAOGA built the Mbuya Dorcas hospital in Harare in 2008 when Zimbabwe was going through an economic meltdown (Biri 2014:158). The end of 2010 saw Guti announcing and launching Talents for 2011 to build the Zimbabwe Ezekiel Guti University in Bindura. The university opened in 2012. 'The church has thus entered what used to be the territory of mainstream churches in terms of providing social services to the public' (Togarasei 2016:3). From the time that it was established, Talents had varied challenges, ranging from drought to economic distress. Such experiences inculcated and instilled perseverance and resilience among members to work harder for their own survival.

As alluded to above, the term 'empowerment' has become a buzzword for modern-day development and particularly gender/feminist acti- 


\section{Gilbert Tarugarira \& Annah Moyo}

vities. Zimbabwe has made efforts through the creation of national institutions such as the Ministry of Women's Affairs and policies like the National Gender Policy to empower and advance the status of women in the country.

Guti proffers that God gave him the vision of how the church would grow in numbers and in holiness if women were liberated to be fully involved in the preaching of the word of God. The first Women's Seminar held in March 1989 at AMFCC, was set 'to deliver women from the mentality of believing that they are second class citizens and good for nothing and yet women are the image of God' (Guti 2000:146). In this sense, participation of women in businesses and the economy became an important indicator of their empowerment, implying that the more women there are in these sectors, the more empowered women are presumed to have become. The establishment of more than 100 Dressmaking and Designing Schools by the ZAOGA church seems to have been targeted at women in order to gain skills and ultimately to become financially secure. Empowerment must lead to a change which is to the advantage of the poor, the disadvantaged, and the marginalized. According to the ZAOGA teachings, psychosocial empowerment starts at a personal level where, through the word of God, an individual must be able to develop a sense of self and individual confidence and capacity, undo the effects of internalized oppression and use these to change their individual circumstances or the wider situation. According to Longwe and Clarke (1994), the provision of training facilities to women should correspond to the welfare stage where women are being given the benefits of training and hopefully be able to meet their basic needs such as food.

The economic self-reliance approach specifically considers women's inability to earn an income and a lack of production capacities as the major reason for women's poverty. Guti states that the School of Talents teaches women to make extra money for themselves. The need to be self-reliant emanates from the combination of wage labor and migration to some workplace which produces a new social identity for females as dependents and appendages of men. However, their resourcefulness and entrepreneurial spirit were usually muted and came to be shaped by the emergence of men as the apparent sole breadwinners. Talents are said to give women the 'ability to control the dollar and discipline in buying' (Guti 2015:34). The church, through the Talents intervention, would empower women through teachings on income generating projects such as soap making, sewing school uniforms, 
peanut butter making, and cooking chips (cf. Maxwell 1998:124). Although these projects appear to be small, they have been effective in terms of changing women's lives. In this light, the church also seems to have taken on board the efficiency approach which argues that women are poor because they do not efficiently utilize the existing factors of production. For Longwe and Clarke (1994:65), women should not be taken as objects of pity but have equal access to training with their male counterparts.

\section{Talents, Empowerment, and Poverty Reduction}

Tarugarira (2013:28) notes that poverty has many magnitudes and that everybody has their own point of view concerning this notion. Looking at the poor people, one cannot regard them as a homogenous group, as they are really diverse. According to Hazell and Haddad (2001:7), poverty can be divided into at least two groups, namely those with physiological deficiencies and those with social deficiencies. The first group almost has no access to earn money, implying that, among others, they do not have access to basic necessities like education, food, and hospitals. The second group, having social deficiencies, lacks essential elements like self-esteem and autonomy to empower themselves and their communities. It is within the context of the above deficiencies that this essay was written. Women have always found it difficult to own immovable property in their own names. However, through Talents, they testified how, from humble beginnings, they had now constructed their own residences.

Some families who used to reside in the high-density suburbs, have bought houses and moved to the low-density suburbs. This essay found that ZAOGA was indeed encouraging women with the consent of their husbands to execute deeds and other documents permitted to be registered in the deeds registry. Some have embarked on impressive building projects involving their own houses in town, as well as their rural homes. In 2002, for example, Southdowns welcomed six families who moved from the Mkoba and Senga high-density suburbs. The following year, two families moved from Ascot, a high-density suburb to the low-density area called Athlone. In a joyous mood, Konde (2013) remarked that her dream had come true because it was her wish to stay kumaDale-Dale, and through Talents, God has done it for her. When people in Gweru talk about kumaDale-Dale, it refers to the splashy 


\section{Gilbert Tarugarira \& Annah Moyo}

suburbs of Harare like Borrowdale, Greendale, and Avondale, largely occupied by the rich. Within the high-density suburbs, people would testify that they had now graduated from being senior lodgers into landlords. Guti emphasizes that home ownership has formed a key part of the people's vision during the 2017 Home Talents. According to Overseer Raviro Gadzikwa (2018b), 'eight families moved from Mkoba 1 to Woodlands, to occupy their own houses. They are now landlords. Two families also moved from Ascot, a high-density suburb to Southview. More than a dozen secured residential stands in the sprouting suburbs of Gweru such as Hertfordshire, Little Eden, and Northgate Heights.' She attributes this progress to Talents. Most importantly, the beneficiaries attributed their success to the God of Ezekiel, the founder and archbishop of ZAOGA who introduced the School of Talents.

Magezi and Banda (2017) argue that the moment prophets are treated as channels of encountering God, problems arise. People end up depending more on the prophets than on God, resulting in the abuse and commercialization of religion. For ZAOGA, Guti is the conduit towards blessedness. He, however, implores people to develop a closer walk with God, advancing that 'Talents are worked with prayer for God to perform signs and wonders. It is prayer that opens closed doors that makes people to buy your products' (Guti 2015:28).

Testimonies from believers also confirm that their success during Home Talents was anchored on small business units that they started as they worked Church Talents. It is important to stress that once the period of Church Talents is over, women are encouraged to continue their production and make money for themselves. The mikando or internal saving and lending schemes then still continue. Whether religious or secular, Allen and Hobane (2004:75) have found that the internal savings and lending project, 'ISAL in Zimbabwe had contributed to increased levels of business and accumulation of consumer assets and quality of housing amongst the majority of participating households'.

From sermons observed, it was established that preachers denounced laziness and strongly rebuked the idle women, telling them that the demon of poverty was going to get the better of them:

Nguva yakapera yemaZRP (Zuva Rose Pamba) nemaDCC (Daddy Chingwa Chapera). Varume ava havana kwavo, mangwana unofuma 
woudzwa kuti handichakudi, buda mumba mangu. Shanda matarenda uite mari yako utenge imba yako! (Chabarwa 2013) ${ }^{3}$.

Such utterances were made to address economic abuse which 'occurs when one intimate partner has control over the other partner's access to economic resources' (Adams \& Greeson 2008:585). Women's projects have now transcended into family businesses, where the foundations of such ventures were Home Talents where men have always been mere appendages.

Musical compositions fundamentally lubricate, broaden, and deepen people's awareness about Talents. In 2012, a musician, Macharika has produced a five-track album on Talents. In this album, he traverses all church districts in Gweru urban, singing about Talents as a school and a broom with which to sweep away poverty. Two songs that he sings, are Matarenda Mutsvairo unotsvaira hurombo! Matarenda chikoro chatakapihwa nababa! ${ }^{4}$ and Kudada nawo kuashandisa! Usagarira maoko haisi cheya!

Muwati (2018:xiii) notes that music is a form of artistic expression which 'unfreezes creative power and unbridles human consciousness from fetters of oppressive inertia'. In Zimbabwe, music has always been inextricably contextured with the dialogue between people about politics, economics, and social life. By resorting to political cum religious songs to propagate Talents, ZAOGA was able to make a spiritual breakthrough among a people 'long traumatised and devastated by an amortising economic and political crisis' (Muwati, Mangena \& Gwekwerere 2013:199). It appears as if people were expressing an awareness of the fact that while the problem that they were dealing with was economic, the solution was spiritual.

We have found that in Gweru urban, the ZAOGA women virtually dominate the informal sector. The women are also into cross border trading. They trade with Botswana, South Africa, Namibia, Zambia, Tanzania, the

3 Time is over for those who spend the whole day at home and those who would always tell their husbands that there is no bread. These men are untrustworthy. Tomorrow you will be divorced and told to pack your bags. Work Talents and make your money and buy your own house!

4 Talents are a broom with which to sweep away poverty. Talents are a school given to us by our father Ezekiel Guti.

5 To be proud of these hands is to make use of them. Do not sit upon them as if they were a chair. 


\section{Gilbert Tarugarira \& Annah Moyo}

United Arab Emirates, China, Malaysia, and Singapore, importing vehicles, clothes, electrical appliances, and varied assortments of goods for resale. At the different marketplaces or Mipedzanhamo (Poverty Busters), ZAOGA women are found to occupy almost half of the market stalls. A census by researchers has established that ZAOGA women, either directly or indirectly operate four in every ten stalls in Gweru city's Central Business District where people sell new and second-hand clothes, imported footwear, electrical appliances, and varied assortments of goods. Of these operators, 22 have registered companies. Every week, on Tuesdays and Thursdays, the female collectivity of Go Quickly and Tell would come together to pray, pour out their woes and seek comfort (Gadzikwa 2018a). During such sessions, specific topics are discussed with them, such as giving to the Lord, how to make money, and Christian motherhood. The general indication is that Tuesdays and Thursdays are special days during which women get a dose of the 'doctrine' of the church to be self-sufficient and self-dependent.

The type of education imparted is to empower women to overcome poverty and ensure that they realize better lives for their families. Through Talents, ZAOGA has therefore been able to provide very poor people with a lasting sense of status, of belonging to a successful institution which they could publicly identify with and be proud of, by the standards of this modern world (Chadoka 2012). Inasmuch as the white missionaries took it as their burden to civilize the Africans, an African Baba, Guti has led his people out of that bondage in many respects. Most women now know how to conduct market research for their products and how to reconcile the buying and selling prices of products to realize some profit among many other entrepreneurial skills.

Despite the multidimensional nature of empowerment, an indicator such as access to credit was looked at to establish the utility of ZAOGA's women empowerment approach through Talents. Among ZAOGA women, success is understood mainly in terms of becoming a successful businessperson, having money to spare for domestic use by way of supplementing the husband's income, affording decent meals, and having a happy family. While women can access loans, mortgages, and credit without the consent of their husbands or male partners, the demand for high levels of collaterals puts formal credit beyond the reach of many women. ZAOGA enhances women's access to credit by supporting and encouraging the setting up of internal savings and lending schemes (mikando). These have met the credit needs of 
low-income women who often find themselves excluded from formal credit due to collateral requirements.

Vanmeenen (2010:46) observes that the mikando model is able 'to accumulate the contributions of its members into a fund from which group members may internally borrow at a predetermined interest rate and terms'. The women take turns to lend contributors a specific small sum on a daily, weekly, or monthly basis. Market vendors and traders use mikando to build up funds for purchasing goods for sale. This form of credit proves to be a crucial resource among ZAOGA women.

Chigara and Mutesarira (2001:68) have conducted a research for the Catholic Relief Services. There they have found that, while the economy pressured the income levels of the populace, it was through mikando that specifically the poor women were disciplined to save their earnings, in this way preventing their spouses to access their money in the house.

We have also established that in all the Gweru urban ZAOGA districts, women had some way of mobilizing funds to provide members with loans for petty trading, food vending, and construction projects. Our research has revealed that the other major attraction of the mikando model is the size and flexibility of this model concerning savings and loans. Irrespective of whether one has received formal education or not, one must create a business or have some main source of revenue. According to Mlambo (2018) from the Ascot district, 'kumudzimai weZAOGA anoshanda matarenda, kurara usina kuverenga mari chivi". Money dwells in the spiritual wallet and in this way business units, run by ZAOGA believers as they work Talents, get the Lord's blessings (Msiza 2012). This concurs with the findings of Gifford (2004) in Ghana in the Mensa Otabil Church where people are also encouraged to own or create businesses so that one has a consistent flowing source of revenue.

The ZAOGA women are encouraged to start small. A mikando scheme by women from Mkoba 1 district in 2012 had loans ranging from USD $\$ 20.00$ to USD $\$ 50.00$ while savings ranged from USD $\$ 5.00$ to USD $\$ 25.00$ on a weekly basis per member (Chirara 2012). This explains why women moved around with baskets carrying sweets, peanuts, and bananas for sale. The cry about minding your own business and saying 'no' to economic

6 For a woman of ZAOGA who works Talents, to sleep without having counted her money, is a sin. 


\section{Gilbert Tarugarira \& Annah Moyo}

abuse seems quite popular, with the women attributing their success to God and their hard work through Talents.

An evaluation of projects initiated through Talents in the seven administrative districts of ZAOGA has revealed an increase in the accumulation of household assets, for example household utensils (cups, forks, kitchen knives, water glasses, plates, and pots, among other items). ISAL also imparted certain religious/spiritual moral values into members' behavior towards one another, for example humility, trust, and support for the vulnerable and each other in times of need. The way in which the ZAOGA mikando model operates, is indeed not different from other non-governmental organization funded schemes like self-help development groups, savings and internal lending communities, rotating savings and credit associations, and group savings and lending. Morduch and Haley (2002) point out the positive impact of microfinance on poverty reduction as it relates to the first six of the seven Millennium Development Goals of Zimbabwe. The goals which are applicable to this essay are the reduction of the proportion of people living in extreme poverty, the promotion of gender equality, and the empowerment of women.

\section{Celebrating Success through Consumerism}

Despite the fact that some of the districts are in high-density and others in low-density suburbs, during sermons, members always appear well off, beautifully dressed, and seem very westernized. The men wear suits while women are clad in stylish fashions. As such, material possessions and the need for consumption help to craft and define one's sense of belonging to and identity with the church. Goods mark the distinction between believers and are equally important in reinforcing identity.

We have observed that measures and illusions of success are equally created through the personal consumption of a unique assemblage or constellation of status goods. Testimonies border on having bought a car or cars and husband and wife independently driving from home on different errands. Overall, Gweru urban has recorded 87 women who confirmed driving cars which were registered in their own names as opposed to their husbands'. The emphasis is currently on today's women with three-in-one signature documents, namely a driver's license, a passport, and title deeds for personal 
immovable properties (Chabarwa 2013). Generally, lifestyles and statusproviding products like a car are mentioned as products that impart status to the respondents. In some cases, it would appear that failure to consume at the proper rhythm has become the object of social reproof. What this entails, is that changes in status that come with church membership and relations are reinforced and given reality by new forms of dress, appropriate gestures, and postures.

Given that the emphasis on Church Talents is based on the law of sowing and reaping, it would not be far from the truth to also argue that more emphasis has been on prosperity and success than personal and moral reformation. Some of the songs like Ane mari ndiye mukuru ${ }^{7}$ are regarded by some respondents to be contrary to what the Bible says about money and worldly riches. Some members of the church feel that true prosperity does not only lie in money. They attack members of the church who smuggle goods across borders and in this way earn money in an illegal manner, referring to them as worse than the devil. Interestingly, testimonies are recorded where some women boast about having smuggled goods and bales of second-hand clothes, in contravention of the country's laws. Senga testifies, 'Patakajambisa mabhero edu tikasabatwa namapurisa, takaona ruoko rwaMwari ${ }^{8}$, (Senga 2012). The contrasts in the points of view, particularly where money is concerned, are extreme. Believers hold different views, some saying: 'The lack of money is the root of all evil' (Mlambo 2018) over against 'The love of money is the root of all evil' (Chauke 2013).

Through the gospel of prosperity and empowerment the church is attacked for promoting vices rather than virtues, drawing distinctions between the rich and the poor and taking most of the time during services to talk about money. While gender relations are outside the scope of this study, some church elders (both male and female) feel that encouraging women to secure assets separately, is a time bomb. Instead of uniting families, the approach is likely going to increase the incidence of broken marriages given that two bulls in the kraal would always fight for supremacy (Chauke 2013). However, according to Guti (2010), true prosperity is not money all the time and to be rich in material things only is not good. He further argues that genuine

7 The one with money is greater.

8 As we smuggled bales of second-hand clothing without being detected by the police, we saw the hand of God. 
prosperity will only come when one is prospering spiritually by putting God first in one's life. In his address on his $52^{\text {nd }}$ anniversary, Guti warned those who hasten to be rich that they will not go unpunished (Guti 2010:17).

\section{Conclusion}

This essay has attempted to show how Guti's teachings on prosperity are linked to the Pan-African cry of revolt against the celebrated view that Africans are backward, inferior, poor, and dependent on the Western world. A deduction can be made that understanding the relationship between Christianity, exploitation, and emancipation has helped the ZAOGA women to see the church as providing the basis for their liberation through psychosocial economic empowerment. Through working Home Talents, women have become successful in business, in this way securing properties and eradicating poverty from their homes. ZAOGA's teachings on prosperity through Talents have helped them to remove the vestiges of the colonial mentality which saw the government and mainstream churches as the initiators of social programs and the providers of amenities, with the people merely playing a passive and submissive role. The gospel of prosperity enshrined in the church and Home Talents seems to be the rediscovery of the true gospel which seeks to move people from poverty to prosperity.

This essay has also shown that although religion has been an important source for the subordination of women in society, it has become an important source to a social movement for human liberation. Contrary to the fact that women were excluded from positions of religious leadership in Christian institutions, the study has shown that church initiated psychosocial empowerment has quashed the stereotypical gender roles which legitimated the subordination of women. This essay confirms that Talents are indeed a 'school' which trains women to be self-sufficient and self-reliant. While there are sceptics who believe that the role of Talents towards the empowerment of women and poverty reduction has been exaggerated, it is beyond doubt that there are indeed benefits derived from participation. 


\section{References}

Adams, A. \& S. Greeson 2008. Development of the scale of economic abuse. Violence against Women 14, 5: 563-588.

Allen, H. \& P. Hobane 2004. Impact evaluation of Kupfuma Ishungu: Consultancy report. Harare: CARE International.

Anderson, A. 2001. African reformation: African initiated Christianity in the $20^{\text {th }}$ century. Asmara: Africa World Press.

Bayu, E.K. 2019. A comparative analysis on the perspectives of African feminism versus Western feminism: Philosophical debate with their criticism and its implications for women's rights in Ethiopia context. International Journal of Sociology and Anthropology 11, 4: 54-58.

Biri, K. 2013. African Pentecostalism and politics in post-colonial Zimbabwe: A comparative critique of the leadership styles of Ezekiel Guti and Robert Mugabe. In Chitando, E. (ed.): Prayers and players: Religion and politics in Zimbabwe. Harare: Sapes Books.

Biri, K. 2014. Migration, transnationalism and the shaping of Zimbabwean Pentecostal spirituality. African Diaspora 7, 1: 141-164.

Bujo, B. 1992. African theology in its social context. Eugene: Wipf \& Stock.

Burton, A. 2001. Thinking beyond the boundaries empire, feminism and the domains of history. Social History 26, 1: 60-71.

Chabarwa, A. 2013. Sermon. May 11, 2013. Gweru.

Chadoka, C. 2012. Sermon. April 14, 2012. Gweru.

Chauke, P. 2013. Interview. May 18, 2013. Gweru.

Chigara, P. \& Mutesarira, L. 2001. Use and impact of saving services among poor people in Zimbabwe: What it means for micro-finance institutions. Unpublished MicroSave paper.

Chirara, A. 2012. Interview. August 6, 2012. Gweru.

Chitando, E. 2013. Introduction: Prayers and Players: Religion and politics in troubled times in Zimbabwe. In Chitando, E. (ed.): Prayers and Players: Religion and politics in Zimbabwe. Harare: Sapes Books.

Fox, L. \& C. Romero 2017. In the mind, the household or the market: Concepts and measurement of women's economic empowerment policy research. Working paper 8079. World Bank Documents.

Gadzikwa, R. 2018a. Sermon. September 15, 2018. Gweru.

Gadzikwa, R. 2018b. Interview. October 29, 2018. Gweru. 
Gifford, P. 1988. The new crusaders: Christianity and the new right in Southern Africa. London: Pluto Press.

Gifford, P. 2004. Ghana's new Christianity: Pentecostalism in a globalising African economy. Bloomington: Indiana University Press.

Guti, E.H. 1994. The church and political responsibility. Harare: EGEA Publications.

Guti, E.H. 2000. New African apostle with the history of the church. Harare: EGEA Publications.

Guti, E.H. 2010. Prosperity that comes through obedience. Harare: EGEA Publications.

Guti, E.H. 2015. Talents/Matarenda. Harare: EGEA Publications.

Gwaze, V. 2019. ZAOGA's journey of a thousand miles. The Sunday Mail. May 12, 2019. Available at: sundaymail.co.zw/zaogas-journey-of-athousand-miles. (Accessed on May 15, 2019.)

Hazell, P.B.R. \& L.J. Haddad 2001. Agricultural research and poverty reduction. International Food Policy Research Institute. Food, Agriculture and the Environment. Discussion paper 34.

Kabeer, N. 2001. Reflections on the measurement of women's empowerment. In Sisask, A. (ed.): Discussing women's empowerment: Theory and practice. Sida Studies 3. Stockholm: Novum Grafiska.

Kohm, L.M. 2008. A Christian perspective on gender equality. Duke Journal of Gender Law and Policy 15: 339-363.

Konde, A. 2013. Interview. October 10, 2013. Gweru.

Longwe, S.H. 1995. Supporting women's development in the third world: Distinguishing between intervention and interference. Gender and Development 3, 1: 47-50.

Longwe, S.H. \& R. Clarke 1994. Gender equality and women's empowerment. New York: UNICEF.

Longwe, S.H. \& R. Clarke 1999. Towards improved leadership for women's empowerment in Africa: Measuring progress and improving strategy. Lusaka: African leadership Forum.

Magezi, V. \& C. Banda 2017. Competing with Christ? A critical Christological analysis of the reliance on Pentecostal prophets in Zimbabwe. In die Skriflig 51, 2: 10 pages. a2273.https://doi.org/ 10.4102/ids.v51i2.2273.

Martin, D. 1990. Tongues of fire: The explosion of Pentecostalism in Latin America. Oxford: Basil Blackwell. 
Maxwell, D. 1998. Delivered from the spirit of poverty? Pentecostalism, prosperity and modernity in Zimbabwe. Journal of Religion in Africa 28, 3: 350-373.

Maxwell, D. 2002. Christianity without frontiers: Shona missionaries and transnational Pentecostalism in Africa. In Maxwell, D. \& I. Lawrie (eds.): Christianity and the African imagination: Essays in honour of Adrian Hastings. Leiden: Brill.

Maxwell, D. 2006. African gifts of the spirit: Pentecostalism and the rise of a Zimbabwean transnational religious movement. Oxford: James Currey. Melton, G.J. \& M. Baumann 2010. Religions of the world: A comprehensive encyclopaedia of beliefs and practices. Santa Barbara: ABC-CLIO.

Mlambo, S. 2018. Interview. May 15, 2018. Gweru.

Morduch, J. \& B. Harley 2002. Analysis of the effects of microfinance on poverty reduction. NYU Wagner Working Paper no. 1014.

Msiza, A. 2012. Sermon. May 18, 2012. Gweru.

Muwati, I. 2018. Introduction. Singing nation: Music and politics in the decade of crisis. In Muwati, I., T. Charamba \& C. Tembo (eds.): Singing nation and politics: Music and the 'decade of crisis' in Zimbabwe 2000-2010. Gweru: Midlands State University Press.

Muwati, I., F. Mangena \& T. Gwekwerere 2013. Manipulating religious songs in electoral politics: The case of Zimbabwe's 2008 harmonised elections. In Chitando, E. (ed.): Prayers and players: Religion and politics in Zimbabwe. Harare: Sapes Books.

Mwase, R. 2012. Dear flamboyant Christian: Letter to the embodiment of prosperity gospel. Available at: bulawayo24.com/index-id-opinion-scletters-byo-104979.html. (Accessed on February 22, 2017.)

Nürnberger, K. 1990. The impact of Christianity on socio-economic developments in South Africa. In Prozesky, M. (ed.): Christianity amidst apartheid: Selected perspectives on the church in South Africa. London: Macmillan.

Pauw, B.A. 1974. The influence of Christianity. In Hammond-Tooke, W.D. (ed.): The Bantu-speaking peoples of Southern Africa. London: Routledge \& Kegan Paul.

Senga, V. 2012. Interview. August 6, 2012. Gweru.

Tarugarira, D. 2013. Impact of rural microfinance on rural poverty in Zimbabwe: The case of Mutasa District 2010-2012. MA Dissertation, 
Department of Development Studies, Midlands State University, Zimbabwe.

Togarasei, L. 2005. Modern Pentecostalism as an urban phenomenon: The case of the family of God in Zimbabwe. Exchange 34, 4: 349-375.

Togarasei, L. 2016. Historicizing Pentecostal Christianity in Zimbabwe. Studia Historica Ecclesiasticae 42, 2: 1-13.

Van Dijk, R. 2002. The soul is the stranger: Ghanaian Pentecostalism and the diasporic contestation of 'flow' and 'individuality'. Culture and Religion 3, 1: 49-65.

Vanmeenen, G. 2010. Savings and internal lending communities: Voices from Africa. Nairobi: Nairobi Catholic Relief Services.

Dr Gilbert Tarugarira Department of Applied Education Midlands State University, Gweru, Zimbabwe tarugarirag@staff.msu.ac.zw Mrs Annah Moyo Gender Institute Midlands State University, Gweru, Zimbabwe moyoan@staff.msu.ac.zw 